\title{
Mortgage Rates and the Corporate Bond Index at the Time of QEs in California
}

\author{
Taewon Kim ${ }^{1}$, Daniel C. Lee ${ }^{1} \&$ Dang Tran ${ }^{2}$ \\ ${ }^{1}$ Department of Finance and Law, College of Business and Economics, California State University Los Angeles, Los \\ Angeles, USA \\ ${ }^{2}$ Department of Economics and Statistics, College of Business and Economics, California State University Los \\ Angeles, Los Angeles, USA \\ Correspondence: Taewon Kim, Department of Finance, College of Business and Economics, California State \\ University Los Angeles, Los Angeles, CA 90032, USA. Tel: 323-343-2921.
}

Received: August 24, 2015

Accepted: September 25, 2015

Online Published: October 7, 2015

doi:10.5430/ijfr.v6n4p151

URL: http://dx.doi.org/10.5430/ijfr.v6n4p151

The authors would like to acknowledge the College of Business and Economics, CSULA, for providing a research grant for this paper as well as Tuan Khong for his data collection assistance.

\begin{abstract}
There are a slew of factors that affect interest rates. A common belief is that the movement of the 10-year Treasury bond yield is the best indicator of the future level of mortgage rates. The mortgage rate is undoubtedly one of the most important factors that affect affordability of housing. On the demand side, it affects the availability of mortgage loans to potential home buyers. Although information on mortgage interest rates is becoming more available, it still is not as easily available as information on bond yields. During the recent, sub-prime loan induced financial crisis, the government intervened extensively in the bond and mortgage markets through various quantitative easing (QE) mechanisms, both directly and indirectly. In this paper, we estimate the extent of the impact of these government policies on the relationship between bond yields and mortgage rates. Our results show that QE policies indeed distorted this relationship.
\end{abstract}

Keywords: correlation between the mortgage rate and corporate bond yield index, economic recession, housing recession, QE

\section{Introduction}

It is well known that the real estate industry, just like the economy as a whole, goes through cycles. Hekman (1985) finds that, for fourteen metropolitan statistical areas (MSAs), the commercial real estate sector is highly cyclical, following the national economic cycle. He also observes that local and regional economic conditions exert important forces on the MSA office market. These findings are reinforced by Dokko, Edelstein, Pomer and Urdang (1991), who demonstrate that local market conditions and macroeconomic conditions, especially inflationary expectations, operate in tandem to generate cyclical outcomes for local real estate markets.

The last seventeen years is no exception. It has seen booms and troughs. Specifically, we witnessed the housing boom period of 1998 through 2006, followed by the housing recession years of 2006 through 2011, which since has been replaced by the current up-market trend that continues to this day. We observe that the two economic recessions defined by the NBER during this period, the first short one from March 2001 to November 2001 and the second one from December 2007 to June 2009 were not in synchronization with the real estate market recessions. The notable event about our study period is that the dramatic fall in housing markets was initially triggered by the sub-prime loan crisis of 2007. Since then, the housing market has recovered much of the losses even though the economic recovery has yet to reach its full potential.

The close relationship between the real estate market and the rest of the economy is not confined to the U.S. In his study of the connection between real estate and the real economy, Quigley (1999) points out that during the Asian financial crisis of the late $1990 \mathrm{~s}$, the regional property market bubble probably had real consequences on the economic conditions of many countries in Asia. 
There are other significant factors that affect the housing market. Many research papers have pointed out that, while interest rates, in addition to employment (unemployment) rates, are most reliable explanation variables in predicting changes in house prices, different markets reveal different sensitivities to the changes in these variables (Miller, Sklarz and Thibodeau (2005) and Ozanne and Thibodeau (1983)). Dokko, Edelstein, Lacayo and Lee (1999) find that, in addition to volatile macroeconomic and income factors, regional and local economic factors exert important influences on the cyclical behavior of real estate markets. For example, Kim, Lee and Tran (2014) observe that the presence of education industry also play a role in the changes in single family home prices. Case and Shiller (1989) emphasize that while single family home prices may not be efficient, the interest rate is a significant factor in determining home prices.

In this paper, our goal is to develop a robust enough econometric model to analyze the changing dynamic relationship between the bond yields and the mortgage rates at the different stages of the real estate and economic cycles in California during 1986-2014, the period in which the Federal Reserve's expansionary monetary policies were in effect. To that end, we develop a model of correlation between mortgage rates and corporate bond yield indexes in California and how the relationship was affected by the housing market cycles and the changes in the Fed policy. Our main interest lies in the behavior of mortgage rates in relation to the corporate bond yield index and how this changing relationship might have affected housing markets in California. During our sample period, the usual correlation between the two rates broke down due to heavy-handed involvement by the Federal Reserve in the fixed income securities market through Quantitative Easing initiatives as well as its influence in the mortgage market through the purchase of treasury bonds and mortgage backed securities (MBSs).

In normal times, all bond rates are the creation of relatively efficient capital markets which in theory incorporates all available information and expectations about the future. Mortgage rates then reflect this information and usually set above treasury yields to reflect risk premiums. However, during recent housing-led recessions, the Fed was aggressively buying Mortgage Backed Securities (MBSs) through QEs and other means in the capital market, in order to help keep mortgage rates low and avoid a further housing and economic disaster. Our research below shows that, as a result, the relationship between mortgage rates and bond yield indexes did indeed change with its accompanying impact on housing markets. We believe that the results of our research present a possible way to help further stabilizing our economic environment: that mortgage lenders might be able to better control their lending risk before the fact by paying attention to this changing relationship between mortgage rates and bond yields, which in turn, would lead to a more stable mortgage and capital market environment.

\section{Model and Sample Description}

In our model, the dependent variable is the mortgage rate. The independent variables in our research are the corporate bond yield index, a dummy variable to represent the housing industry's recessionary period and another dummy variable to indicate the expansionary period. Given that the real estate downturns in California did not coincide with the two economic recessions determined by NBER, we also use two dummy variables to represent the two economic recessionary periods and set the dummy variable to zero to indicate the economic expansion period. For mortgage rates, we used monthly statistics from sixty-one cities in California with the population of over 100,000 as of 2005 .

Our dynamic panel data model is as follows:

$$
\begin{gathered}
D L M R_{i t}=\beta_{0}+\beta_{1} \times D L C B I_{i t}+\beta_{2} \times R E C E S S 1_{i t}+\beta_{3} \times R E C E S S 2_{i t}+\beta_{4} \times H P D 1_{i t}+\beta_{5} \times H P D 2_{i t}+ \\
\beta_{6} \times D L M R_{i t}(-1)+\beta_{7} \times D L M R_{i t}(-2)+u_{i}+\varepsilon_{i t}
\end{gathered}
$$

RECESS $1=$ recession period as defined by National Bureau of Economic Research, i.e. RECESS $1=1$ for period from March 2001 to November 2001, = 0 otherwise (See NBER, Cycle US Business Expansions and Contractions, BUSINESS CYCLE REFERENCE DATES).

RECESS 2 = recession period as defined by National Bureau of Economic Research, i.e. Recess $2=1$ for period from December 2007 to June 2009, = 0 otherwise (See NBER, Cycle US Business Expansions and Contractions, BUSINESS CYCLE REFERENCE DATES).

HPD1 $=1$ for Feb. 1996 to Feb. 2006 and HPD1 = 0 otherwise (Period 1 in which housing prices were rising from February 1996 to February 2006)

HPD2 = 1 for March 2006 to Jan 2012, HPD2= 0 otherwise. (Period 2 in which housing prices were falling from March 2006 to January 2012)

$D L M R$ is the first difference of natural logarithm of mortgage rate at time t. This data is not available for individual cities over time. DLCBI is the logarithm of the corporate bond yield index, RECESSI is the dummy variable $=1$ for March 2001 to November 2001 and zero otherwise, RECESS2 is the dummy variable $=1$ for December 2007 to June 
2009, HPD1 = 1 in which housing prices were rising from February 1996 to February 2006, HPD2 = 1 in which housing prices were falling from March 2006 to January 2012 and zero otherwise. In fact, from February 2012 up to now is period 3 when housing prices have been rising.

In addition, $u_{i}$ represents between-city errors created by all other unobserved time-invariant variables that influence the dependent variable. The term $\varepsilon_{i t}$ is the random disturbance for the $i$ th city at $t$ th time period with $\mathrm{E}\left(\varepsilon_{i t}\right)=0$. It is assumed that $\varepsilon_{i t}$ is uncorrelated with the independent variables and with $\mathrm{u}_{i}$ and that $\operatorname{COV}\left(\varepsilon_{i t}, \varepsilon_{i s}\right)=0$ for $t \neq s$.

Our sixty-two sample California cities with the population of 100,000 or more as of 2005 are the following: Anaheim, Antioch, Bakersfield, Berkeley, Burbank, Chula Vista, Concord, Corona, Costa Mesa, Daly City, Downey, El Monte, Elk Grove, Escondido, Fairfield, Fontana, Fremont, Fresno, Fullerton, Garden Grove, Glendale, Hayward, Huntington Beach, Inglewood, Irvine, Lancaster, Long Beach, Los Angeles, Modesto, Moreno Valley, Norwalk, Oakland, Oceanside, Ontario, Orange, Oxnard, Palmdale, Pasadena, Pomona, Rancho Cucamonga, Richmond, Riverside, Roseville, Sacramento, Salinas, San Bernardino, San Diego, San Francisco, San Jose, Ventura, Santa Ana, Santa Clara, Santa Clarita, Santa Rosa, Simi Valley, Stockton, Sunnyvale, Thousand Oaks, Torrance, Vallejo, Visalia and West Covina. But Elk Grove doesn't have data and the list is reduced to 61 in our work below.

\section{Empirical Analysis and Results}

Our research below shows that the correlation between the mortgage rates (MR) and the corporate bond yield index (CBI) is indeed strong, as shown by the regression coefficients of the corporate bond index variable. It is notable that as the sample period nears the housing collapse of the 2000 s, the regression coefficients steadily decrease in value as we hypothesized from the beginning, i.e. the effect of the corporate bond yield index on the mortgage rates becomes consistently weaker over time (see Table 1). We attribute this to the Federal Reserve's policies at the time of artificially keeping mortgage rates low through expansionary monetary policies under Alan Greenspan after the 2001 recession and QE1, QE2, and QE3 after the 2007-2009 recession, and that naturally, the impact is shown in a more pronounced way, the closer the sample period was to the time when these interventions were in effect. We note however, that the explanatory power $\mathrm{R}^{2}$ and F-statistics become also smaller at the same time although they are still noticeably significant.

Table 1. Testing the hypothesis on relationship between MR and CBI

\begin{tabular}{|c|c|c|c|c|c|c|}
\hline \multicolumn{7}{|c|}{ Dependent Variable: DLMR } \\
\hline Variable & $1996-2014$ & $1997-2014$ & 1998-2014 & $1999-2014$ & $2000-2014$ & $2001-2014$ \\
\hline DLCBI & $\begin{array}{c}0.761^{*} \\
(142.96)\end{array}$ & $\begin{array}{c}0.753^{*} \\
(138.18)\end{array}$ & $\begin{array}{c}0.749 * \\
(132.58)\end{array}$ & $\begin{array}{c}0.747^{*} \\
(127.88)\end{array}$ & $\begin{array}{c}0.737^{*} \\
(121.66)\end{array}$ & $\begin{array}{c}0.729 * \\
(115.63)\end{array}$ \\
\hline RECESS1 & $\begin{array}{c}-0.00609^{*} \\
(-6.91)\end{array}$ & $\begin{array}{c}-0.00611^{*} \\
(-6.82)\end{array}$ & $\begin{array}{c}-0.00648^{*} \\
(-7.04)\end{array}$ & $\begin{array}{c}-0.00658^{*} \\
(-6.90) \\
\end{array}$ & $\begin{array}{c}-0.00657^{*} \\
(-6.74)\end{array}$ & $\begin{array}{c}-0.00761^{*} \\
(-7.52)\end{array}$ \\
\hline RECESS2 & $\begin{array}{c}-0.00614^{*} \\
(-8.95)\end{array}$ & $\begin{array}{c}-0.00617^{*} \\
(-8.88)\end{array}$ & $\begin{array}{c}-0.00611^{*} \\
(-8.59)\end{array}$ & $\begin{array}{c}-0.00606^{*} \\
(-8.30)\end{array}$ & $\begin{array}{c}-0.00599^{*} \\
(-8.09)\end{array}$ & $\begin{array}{c}-0.00599^{*} \\
(-7.90) \\
\end{array}$ \\
\hline HPD1 & $\begin{array}{c}0.000935^{*} \\
(3.86) \\
\end{array}$ & $\begin{array}{c}0.000871^{*} \\
(3.40)\end{array}$ & $\begin{array}{c}0.00125^{*} \\
(4.47) \\
\end{array}$ & $\begin{array}{c}0.00136^{*} \\
(4.40) \\
\end{array}$ & $\begin{array}{c}0.00130^{*} \\
(3.81) \\
\end{array}$ & $\begin{array}{c}0.00228^{*} \\
(5.88) \\
\end{array}$ \\
\hline HPD2 & $\begin{array}{c}-0.000927^{*} \\
(-2.61)\end{array}$ & $\begin{array}{c}-0.00101^{*} \\
(-2.81) \\
\end{array}$ & $\begin{array}{c}-0.00103 * \\
(-2.79) \\
\end{array}$ & $\begin{array}{c}-0.00104^{*} \\
(-2.74) \\
\end{array}$ & $\begin{array}{c}-0.00110^{*} \\
(-2.88) \\
\end{array}$ & $\begin{array}{r}-0.00118^{*} \\
(-3.00) \\
\end{array}$ \\
\hline $\operatorname{DLMR}(-1)$ & $\begin{array}{l}0.241^{*} \\
(45.14) \\
\end{array}$ & $\begin{array}{l}0.242^{*} \\
(43.64) \\
\end{array}$ & $\begin{array}{l}0.248^{*} \\
(43.17) \\
\end{array}$ & $\begin{array}{l}0.249^{*} \\
(41.94)\end{array}$ & $\begin{array}{l}0.263^{*} \\
(42.72)\end{array}$ & $\begin{array}{l}0.262^{*} \\
(40.84)\end{array}$ \\
\hline DLMR(-2) & $\begin{array}{l}-0.139^{*} \\
(-25.97) \\
\end{array}$ & $\begin{array}{l}-0.148^{*} \\
(-26.71) \\
\end{array}$ & $\begin{array}{l}-0.151^{*} \\
(-26.30) \\
\end{array}$ & $\begin{array}{l}-0.150^{*} \\
(-25.26) \\
\end{array}$ & $\begin{array}{l}-0.165^{*} \\
(-26.63) \\
\end{array}$ & $\begin{array}{l}-0.169^{*} \\
(-26.29)\end{array}$ \\
\hline $\begin{array}{l}\text { Adjusted } \\
\text { R-squared }\end{array}$ & 0.65 & 0.64 & 0.64 & 0.64 & 0.63 & 0.63 \\
\hline F-Statistics & $3,417.11$ & $3,199.24$ & $2,956.90$ & $2,762.51$ & $2,562.86$ & $2,341.42$ \\
\hline Durbin-Watson & 1.985 & 1.982 & 1.985 & 1.984 & 1.981 & 1.994 \\
\hline $\begin{array}{c}\text { Number of } \\
\text { Observations }\end{array}$ & 13,115 & 12,566 & 11,834 & 11,102 & 10,370 & 9,638 \\
\hline
\end{tabular}

Note: Figures in parentheses are t-statistics. * indicates significance at $1 \%$ level or better. 
All quantitative variables with first difference have been tested for unit root and found to be stationary except DLMR. The lags of log of mortgage rates up to 2 months are used as independent variables to ensure Durbin-Watson statistic to be close to 2 . Without these lags, the residuals would have been serially correlated, as pointed out by Capozza, Hendershott and Mack (2004), for example. As a result, our panel data regression is qualified as a dynamic one.

The variable DLMR presents a problem since it gives same observations for all cities over time. No random effects are available for cross-section when DLMR is included. Fixed effects cannot be obtained for either cities or months as they create singularity. Random effects for months are so small and random effects for cities are zero. Thus, the only choice is the ordinary pooled least squares with no fixed or random effects. We stopped running regression after 2001 as the dummy variables were so close to one another that the relationship between them was rendered singular in the regression.

In a previous paper, Kim, Lee and Tran (2014) observed and confirmed that a rising percentage change in unemployment would lower the percentage change in housing price. In this paper we further observed that in a period when the housing prices were falling (as evidenced by the period from March 2006 to January 2012), the percentage rise in the mortgage rate would be depressed as evidenced by the negative coefficients for HPD2. The rest of the coefficients have the right signs as expected. All coefficients are significant at $1 \%$ level of significance. The significance and positive sign of coefficients of HPD1 confirms that the rising housing prices during the February 1996 - February 2006 period had the effects of pushing up the mortgage rates, while those of HPD2 indicate that the falling housing prices from March 2006 to January 2012 were contributors to the falling mortgage rates as they did in fact occur. In addition, the coefficients of RECESS1 and RECESS 2 are both negative and significant at $1 \%$ or better. This suggests mortgage rates were affected both by the real estate cycles and economic business cycles. This observation suggests that the policy maker need to pay additional attention to the changing real estate cycles, because they did not necessarily coincide with the official designation of the economic business cycle by NBER.

\section{Concluding Remarks}

In this paper we developed a model to establish relationship between mortgage interest rates and corporate bond yield indexes in California and how they were affected by the bullishness or bearishness of the housing markets and the changes in the Fed policy. Starting in 1998 through 2011, the housing industry went through a cycle of boom and fall, the fall that was initially triggered by the sub-prime loan crisis. We break down the last seventeen years of the housing market into the boom period of 1998 through 2006, the recession years of 2006 through 2011, and the current up-market trend that continues to this day. These are interesting time periods in which the usual correlation between the two rates broke down due to the heavy-handed involvement of the Federal Reserve in the fixed income securities market through Quantitative Easing initiatives as well as in the mortgage market. We observe that the two economic recessions defined by NBER during this period, the short first one from March 2001 to November 2001 and the second one from December 2007 to June 2009, were not in synchronization with the real estate market recessions.

The results are as expected. The closer the sample period gets to the beginning of the subprime-led financial crisis, the weaker the correlation between mortgage rates and the corporate bond index, showing that various government interventions in the bond market such as QE indeed distorted this relationship. How this distorted relationship between the mortgage rates and the bond yields affected the mortgage rates and eventually, the housing market, is a question left for further study.

\section{References}

Capozza, D., Hendershott, P., \& Mack, C. (2004). An Anatomy of Price Dynamics in Illiquid Markets: Analysis and Evidence from local Housing Markets. Real Estate Economics, 32, 1-32. http://dx.doi.org/10.1111/j.1080-8620.2004.00082.x

Case, K., \& Shiller, R. E. (1989). The Efficiency of the Market for Single-Family Homes. American Economic Review, 79(1), 125-137.

Dokko, Y., Edelstein, R., Lacayo, A., \& Lee, D. (1999). Real Estate Income and Value Cycles: A Model of Market Dynamics. Journal of Real Estate Research, 18(1), 69-95. http://dx.doi.org/10.1111/1540-6229.00540

Dokko, Y., Edelstein, R., Pomer, M., \& Urdang, S. (1991). Determinants of the Rate of Return for Nonresidential Real Estate: Inflation Expectations and Market Adjustment Lags. Journal of the American Real Estate and Urban Economics Association, 19(1), 52-69. 
Hekman, J. (1985). Rental Price Adjustment and Investment in the Office Market Dynamics. Journal of the American Real Estate and Urban Economics Association, 2, 32-47. http://dx.doi.org/10.1111/1540-6229.00339

Kim, T., Lee, D., \& Tran, D. (2014). The Effect of the Presence of Educational Sectors on Housing Prices: The Case of California. International Research Journal of Applied Finance, 5(3), 277-280. Retrieved from https://irjaf.com/uploads/IRJAF_Vol_V_Issue_3_March_2014

Miller, N. G., Sklarz, M. A., \& Thibodeau, T. G. (2005). The Impact of Interest Rates and Employment on Nominal Housing Prices. International Real Estate Review, 8(1), 27-43. https://ideas.repec.org/e/pth30.html

NBER. Cycle US Business Expansions and Contractions. BUSINESS CYCLE REFERENCE DATES NBER. Retrieved from www.nber.org/cycles.html

Quigley, J. M. (1999). Real Estate Prices and Economic Cycles. International Real Estate Review, 2(1), 1-21. Retrieved from https://ideas.repec.org/s/ire/issued.html

Appendix. Hypothesis on Relationship between MR and CBI

1. Dependent Variable: DLMR

Sample (adjusted): 1996M04 2014M02

Included observations: 215 after adjustments

Cross-sections included: 61

Total pool (balanced) observations: 13115

\begin{tabular}{|c|c|c|c|c|}
\hline Variable & Coefficient & Std. Error & t-Statistic & Prob. \\
\hline DLCBI & 0.760841 & 0.005322 & 142.9618 & 0.0000 \\
\hline RECESS1 & -0.006085 & 0.000881 & -6.907487 & 0.0000 \\
\hline RECESS2 & -0.006140 & 0.000686 & -8.952197 & 0.0000 \\
\hline HPD1 & 0.000935 & 0.000242 & 3.858394 & 0.0001 \\
\hline HPD2 & -0.000927 & 0.000355 & -2.614449 & 0.0089 \\
\hline $\operatorname{DLMR}(-1)$ & 0.240620 & 0.005331 & 45.13684 & 0.0000 \\
\hline $\operatorname{DLMR}(-2)$ & -0.138684 & 0.005340 & -25.96877 & 0.0000 \\
\hline R-squared & 0.646013 & Mean dependent var & & -0.002711 \\
\hline Adjusted R-squared & 0.645851 & S.D. dependent var & & 0.033303 \\
\hline S.E. of regression & 0.019819 & Akaike info criterion & & -5.003840 \\
\hline Sum squared resid & 5.148614 & Schwarz criterion & & -4.999847 \\
\hline Log likelihood & 32819.68 & Hannan-Quinn criter. & & -5.002506 \\
\hline Durbin-Watson stat & 1.985416 & & & \\
\hline
\end{tabular}

$\begin{array}{ccc}\text { Variable } & \text { Sign } \\ \text { DLCBI } & + & \text { Comments } \\ \text { RECESS1 } & - & \text { Mecession has depressed the mortgage rate hike or reduced it upward movements } \\ \text { RECESS2 } & - & \text { Same as above } \\ \text { HPD1 } & + & \text { The bullish housing market increased the upward momentum for the mortgage rates } \\ \text { HPD2 } & - & \text { The housing recession depressed the mortgage rates due to the lack of the demand for the housing units in } \\ & & \text { the market } \\ \text { DLMR(-1) } & + & \text { Mortgage rates movement seems to demonstrate a mean-reversion process. } \\ \text { DLMR(-2) } & - \text { Mortgage rates movement seems to demonstrate a mean-reversion process. }\end{array}$


2. Dependent Variable: DLMR

Method: Pooled Least Squares

Sample: 1997M01 2014M02

Included observations: 206

Cross-sections included: 61

Total pool (balanced) observations: 12566

\begin{tabular}{ccccc}
\hline \hline Variable & Coefficient & Std. Error & t-Statistic & Prob. \\
\hline \hline DLCBI & 0.753169 & 0.005450 & 138.1841 & 0.0000 \\
RECESS1 & -0.006105 & 0.000895 & -6.824552 & 0.0000 \\
RECESS2 & -0.006168 & 0.000695 & -8.880577 & 0.0000 \\
HPD1 & 0.000871 & 0.000256 & 3.398403 & 0.0007 \\
HPD2 & -0.001007 & 0.000359 & -2.805015 & 0.0050 \\
DLMR(-1) & 0.241709 & 0.005538 & 43.64345 & 0.0000 \\
DLMR(-2) & -0.147773 & 0.005533 & -26.70723 & 0.0000 \\
\hline R-squared & & & & -0.002810 \\
Adjusted R-squared & 0.640714 & Mean dependent var & & 0.033465 \\
S.E. of regression & 0.640543 & S.D. dependent var & & -4.979209 \\
Sum squared resid & 0.020064 & Akaike info criterion & & -4.975066 \\
Log likelihood & 5.055868 & Schwarz criterion & -4.977822 \\
Durbin-Watson stat & 31291.37 & Hannan-Quinn criter. & & \\
\hline \hline
\end{tabular}

$\begin{array}{ccc}\text { Variable } & \text { Sign } & \text { Comments } \\ \text { DLCBI } & + & \text { Mortgage rates tend to move in tandem with the bond rates. } \\ \text { RECESS1 } & - & \text { Recession has depressed the mortgage rate hike or reduced it upward movements } \\ \text { RECESS2 } & - & \text { Same as above } \\ \text { HPD1 } & + & \text { The bullish housing market increased the upward momentum for the mortgage rates } \\ \text { HPD2 } & - & \text { The housing recession depressed the mortgage rates due to the lack of the demand for the housing units } \\ \text { DLMR(-1) } & + & \text { in the market } \\ \text { DLMR(-2) } & - & \text { Mortgage rates movement seems to demonstrate a mean-reversion process. }\end{array}$




\section{Dependent Variable: DLMR}

Method: Pooled Least Squares

Sample: 1998M01 2014M02

Included observations: 194

Cross-sections included: 61

Total pool (balanced) observations: 11834

\begin{tabular}{|c|c|c|c|c|}
\hline Variable & Coefficient & Std. Error & $\mathrm{t}$-Statistic & Prob. \\
\hline DLCBI & 0.749169 & 0.005651 & 132.5791 & 0.0000 \\
\hline RECESS1 & -0.006479 & 0.000920 & -7.039761 & 0.0000 \\
\hline RECESS2 & -0.006107 & 0.000711 & -8.593223 & 0.0000 \\
\hline HPD1 & 0.001248 & 0.000279 & 4.473244 & 0.0000 \\
\hline HPD2 & -0.001026 & 0.000367 & -2.791886 & 0.0052 \\
\hline $\operatorname{DLMR}(-1)$ & 0.247979 & 0.005744 & 43.17268 & 0.0000 \\
\hline $\operatorname{DLMR}(-2)$ & -0.151366 & 0.005756 & -26.29644 & 0.0000 \\
\hline R-squared & 0.636395 & Mean dependent var & & -0.002611 \\
\hline Adjusted R-squared & 0.636210 & S.D. dependent var & & 0.034029 \\
\hline S.E. of regression & 0.020525 & Akaike info criterion & & -4.933788 \\
\hline Sum squared resid & 4.982264 & Schwarz criterion & & -4.929423 \\
\hline Log likelihood & 29200.22 & Hannan-Quinn criter. & & -4.932322 \\
\hline Durbin-Watson stat & 1.984519 & & & \\
\hline
\end{tabular}

\footnotetext{
Variable Sign

Comments

DLCBI + Mortgage rates tend to move in tandem with the bond rates.

RECESS1 - Recession has depressed the mortgage rate hike or reduced it upward movements

RECESS2 - Same as above

HPD1 + The bullish housing market increased the upward momentum for the mortgage rates

HPD2 - The housing recession depressed the mortgage rates due to the lack of the demand for the housing units in the market

$\operatorname{DLMR}(-1)+$ Mortgage rates movement seems to demonstrate a mean-reversion process.

$\operatorname{DLMR}(-2) \quad$ - Mortgage rates movement seems to demonstrate a mean-reversion process.
} 
4. Dependent Variable: DLMR

Method: Pooled Least Squares

Sample: 1999M01 2014M02

Included observations: 182

Cross-sections included: 61

Total pool (balanced) observations: 11102

\begin{tabular}{crcrr}
\hline Variable & Coefficient & Std. Error & t-Statistic & Prob. \\
\hline DLCBI & 0.746703 & 0.005839 & 127.8817 & 0.0000 \\
RECESS1 & -0.006575 & 0.000953 & -6.899475 & 0.0000 \\
RECESS2 & -0.006060 & 0.000730 & -8.295609 & 0.0000 \\
HPD1 & 0.001356 & 0.000308 & 4.403223 & 0.0000 \\
HPD2 & -0.001035 & 0.000378 & -2.740721 & 0.0061 \\
DLMR(-1) & 0.249034 & 0.005938 & 41.93682 & 0.0000 \\
DLMR(-2) & -0.150110 & 0.005943 & -25.25841 & 0.0000 \\
\hline \hline R-squared & 0.635444 & Mean dependent var & & -0.002480 \\
Adjusted R-squared & 0.635247 & S.D. dependent var & & 0.034927 \\
S.E. of regression & 0.021094 & Akaike info criterion & & -4.879019 \\
Sum squared resid & 4.936831 & Schwarz criterion & & -4.874407 \\
Log likelihood & 27090.43 & Hannan-Quinn criter. & & -4.877466 \\
Durbin-Watson stat & 1.983987 & & \\
\hline \hline
\end{tabular}

\footnotetext{
Variable Sign

Comments

DLCBI + Mortgage rates tend to move in tandem with the bond rates.

RECESS1 - Recession has depressed the mortgage rate hike or reduced it upward movements

RECESS2 - Same as above

HPD1 + The bullish housing market increased the upward momentum for the mortgage rates

HPD2 - The housing recession depressed the mortgage rates due to the lack of the demand for the housing units in the market

$\operatorname{DLMR}(-1)+$ Mortgage rates movement seems to demonstrate a mean-reversion process.

DLMR(-2) - Mortgage rates movement seems to demonstrate a mean-reversion process.
} 


\section{Dependent Variable: DLMR}

Method: Pooled Least Squares

Sample: 2000M01 2014M02

Included observations: 170

Cross-sections included: 61

Total pool (balanced) observations: 10370

\begin{tabular}{ccccr}
\hline \hline Variable & Coefficient & Std. Error & t-Statistic & Prob. \\
\hline DLCBI & & & & \\
RECESS1 & 0.737086 & 0.006059 & 121.6553 & 0.0000 \\
RECESS2 & -0.006569 & 0.000974 & -6.743457 & 0.0000 \\
HPD1 & -0.005991 & 0.000740 & -8.093090 & 0.0000 \\
HPD2 & 0.001302 & 0.000341 & 3.814174 & 0.0001 \\
DLMR(-1) & -0.001102 & 0.000383 & -2.879895 & 0.0040 \\
DLMR(-2) & 0.263239 & 0.006161 & 42.72437 & 0.0000 \\
R-squared & -0.164613 & 0.006181 & -26.63356 & 0.0000 \\
Adjusted R-squared & 0.633878 & Mean dependent var & & -0.003640 \\
S.E. of regression & 0.633666 & S.D. dependent var & & 0.035308 \\
Sum squared resid & 0.021370 & Akaike info criterion & & -4.852938 \\
Log likelihood & 4.732754 & Schwarz criterion & -4.848046 \\
Durbin-Watson stat & 25169.48 & Hannan-Quinn criter. & & -4.851285 \\
\hline \hline
\end{tabular}

\begin{tabular}{ccl}
\hline \hline Variable & Sign & \\
DLCBI & + & Mortgage rates tend to move in tandem with the bond rates. \\
RECESS1 & - & Recession has depressed the mortgage rate hike or reduced it upward movements \\
RECESS2 & - & Same as above \\
HPD1 & + & The bullish housing market increased the upward momentum for the mortgage rates \\
HPD2 & - & The housing recession depressed the mortgage rates due to the lack of the demand for the housing \\
& & units in the market
\end{tabular}


6. Dependent Variable: DLMR

Method: Pooled Least Squares

Date: 01/13/15 Time: 10:05

Sample: 2001M01 2014M02

Included observations: 158

Cross-sections included: 61

Total pool (balanced) observations: 9638

\begin{tabular}{ccccc}
\hline \hline Variable & Coefficient & Std. Error & t-Statistic & Prob. \\
\hline \hline DLCBI & 0.729016 & 0.006305 & 115.6258 & 0.0000 \\
RECESS1 & -0.007606 & 0.001011 & -7.521416 & 0.0000 \\
RECESS2 & -0.005990 & 0.000758 & -7.898305 & 0.0000 \\
HPD1 & 0.002276 & 0.000387 & 5.877441 & 0.0000 \\
HPD2 & -0.001178 & 0.000392 & -3.004539 & 0.0027 \\
DLMR(-1) & 0.261949 & 0.006414 & 40.84150 & 0.0000 \\
DLMR(-2) & -0.169220 & 0.006436 & -26.29264 & 0.0000 \\
\hline \hline R-squared & 0.629899 & Mean dependent var & & -0.003461 \\
Adjusted R-squared & 0.629668 & S.D. dependent var & & 0.035968 \\
S.E. of regression & 0.021888 & Akaike info criterion & & -4.805027 \\
Sum squared resid & 4.614081 & Schwarz criterion & & -4.799816 \\
Log likelihood & 23162.42 & Hannan-Quinn criter. & & -4.803260 \\
Durbin-Watson stat & 1.994389 & & \\
\hline \hline
\end{tabular}

\begin{tabular}{ccc} 
Variable & Sign & \multicolumn{1}{c}{ Comments } \\
DLCBI & + & Mortgage rates tend to move in tandem with the bond rates. \\
RECESS1 & - & Recession has depressed the mortgage rate hike or reduced it upward movements \\
RECESS2 & - & Same as above \\
HPD1 & + & The bullish housing market increased the upward momentum for the mortgage rates \\
HPD2 & - & The housing recession depressed the mortgage rates due to the lack of the demand for the housing \\
DLMR(-1) & + & Mnits in the market \\
DLMR(-2) & - & Mortgage rates movement seems to demonstrate a mean-reversion process.
\end{tabular}

